\title{
JM
}

Volume 7 No. 1 (April 2019)

(C) The Author(s)

\section{KETIDAKTERATURAN SIKLUS HAID, BERAT BADAN DAN FLOUR ALBUS TERHADAP AKSEPTOR DEPOPROGESTERON UNTUK MELANJUTKAN SUNTIK}

\section{MENSTRUAL CYCLE IRREGULARITIES, WEIGHT AND FLOUR ALBUS AGAINST DEPOPROGESTERONE ACCEPTOR TO CONTINUE INJECTIONS}

\author{
YESI PUTRI \\ FAKULTAS ILMU KESEHATAN UNIVERSITAS DEHASEN \\ Email: yesiputri37@gmail.com
}

\begin{abstract}
ABSTRAK
Minat akseptor depoprogesteron untuk melanjutkan suntik depoprogesteron sebagai sebuah kesimpulan kontrasepsi suntik depoprogesteron merupakan salah satu metode kontrasepsi yang banyak digunakan akseptor.Tujuan dari penelitian ini adalah untuk mengetahui Hubungan Ketidakteraturan Siklus Haid, Peningkatan Berat Badan dan Flour Albus Terhadap Minat Akseptor Depoprogesteron Untuk Melanjutkan Suntik Depoprogesteron di Bpm Resti Desa Sibak Provinsi Bengkulu Tahun 2018. Metode penelitian ini termasuk dalam penelitian kuantitatif dengan penelitian deskritif analtik dan menggunakan desain Cross Sectional. Data yang digunakan adalah data primer. Populasi penelitian ini adalah ibu yang menggunakan suntik depoprogesteron sebanyak 297 pasangan usia subur, sampel penelitian menggunakan responden 170 orang. Dari hasil penelitian univariat $62,9 \%$ minat melanjutkan dan $37,1 \%$ tidak melanjutkan,64,7\% siklus haid teratur dan 35,3\% tidak teratur, 72,9\% peningkatan berat badan bertambah dan $27,1 \%$ bertambah, 60,6\% keputihan dan 39,9\% tidak keputihan. Berdasarkan uji chi square didapatkan nilai ketidakteraturan siklus Pvalue 0,09 dan OR 2,425 CI (1,2924,550) peningkatan berat badan Pvalue 0,03 dan OR 2,690 CI $(1,428-5,064)$ dan flour albus Pvalue 0,016 dan OR 2,281 CI (1,213-4,292), sehingga dapat disimpulkan ada hubungan antara melanjutkan suntik depoprogesteron di Bpm Resti Desa Sibak. Diharapkan dapat dijadikan masukan minat akseptor untuk melanjutkan suntik depoprogesteron bertujuan untuk meningkat akseptor dalam mengikuti keluarga berencana.
\end{abstract}

Kata Kunci: Haid, berat badan, flour albus

\begin{abstract}
Depoprogesteron acceptor interest to continue injecting depoprogesteronas a conclusion depoprogesteron injectable contraceptives is one of the many methods of contraception used by acceptors. The purpose of this study was to determine the relationship Menstrual Cycle Disorder, Improved Weight Loss and Flour Albus Against Interests Acceptor Depoprogesteron To Continue Injectable Depoprogesteron in BPM Bidan Desa Resti Drill Bengkulu Province Year 2018. This research method included in the quantitative research with descriptive research analtik and use Desai Cross Sectional. The data used are the indigenous primary. The study population was women who use injectable depoprogesteron 297 couples of childbearing age, sample size of 170 people. From the results of the univariate study $62.9 \%$ and $37.1 \%$ continuing
\end{abstract}


interest not to continue, $64.7 \%$ regular menstrual cycles irregular and $35.3 \%, 72.9 \%$ increase in weight gain and a $27.1 \%$ increase, $60,6 \%$ white and $39.9 \%$ were white. Based on bivariate statistical test cycle irregularity pvalue value (0.09) and OR 2,425 CI (1.292 to 4.550) increase in body weight pvalue (0.03) and OR 2,690 CI (1.428 to 5.064) and flour albuspvalue (0.016) means pvalue $<2.281$ and OR 0.05 CI $(1.213$ to 4.292$)$, so that it can be concluded there is a relationship between continuing injecting depoprogesteron in Bpm Resti Village Sibak. The results of this study are expected to be used as input acceptor interest to continue injecting depoprogesteron aims to increase family planning acceptors in following.

Keywords: Menstruation,weight, flower albus

\section{PENDAHULUAN}

Keluarga Berencana merupakan program yang ada di hampir setiap Negara Berkembang termasuk Indonesia, program ini bertujuan untuk mengotrol jumlah penduduk dengan mengurangi jumlah anak yang dilahirkan oleh perempuan usia 15-49 tahun.

Metode keluarga berencana suntik telah menjadi bagian dari gerakan keluarga berencana nasional serta peminatnya makin bertambah, tingginya minat pemakai keluarga berencana suntik dikarenakan penggunaannya aman, sederhana. Salah satu alasan penghentian penggunaan kontrasepsi suntik adalah munculnya efek samping yang dirasakan yaitu gangguan siklus haid, keputihan, pertambahan berat badan dan sampai saat ini tidak ada satupun alat kontrasepsi yang bebas dari kegagalan maupun efek samping (Marmi, 2015)

Menurut (World Health Organization) tahun 2013 penduduk republik Cina 1.336.718.015 jiwa, negara ini banyak menggunakan alat kontrasepsi suntik 14,3\%, India 1.189.172.906 jiwa menggunakan alat kontrasepsi suntik 15,9\%, Amerika Serikat 311.050. 977 jiwa menggunakan kontrasepsi suntik 13,6 \%, disusul Negara di Asia dengan jumlah penduduk menempati peringkat 4 yaitu Indonesia yang jumlah penduduknya sekitar 245.613.043 jiwa menggunakan alat kontarsepsi suntik 32,1\% (WHO, 2013).

Berdasarkan Hasil Survei Demografi dan Kependudukan Indonesia pada tahun 2013 Pola pemakaian Kontrasepsi terbesar adalah Suntik 31,6 \%, Pil 13,2\%,Intra Uterine Devices $4,8 \%$, Implant 2,8 \% , Kondom 1,3
$\%$, Metode operatif wanita 3,1\%, dan kontap pria metode operatif pria $0,2 \%$, Pantang Berkala 1,5\%, senggama terputus $2,2 \%$, dan metode lainnya $0,4 \%$. Dilihat pengguna keluarga berencana suntik dari tahun 1991 sampai 2010yaitu pada tahun 1991 mengalami kenaikan 11,7 \%, 1994 menjadi 15,2\%, 1998menjadi 21,2\%. 2004 menjadi 27,8 \% dan 2008 mencapai 31,6\% dengan angka kegagalan sekitar 0,3 per 100 wanita selama tahun pertama (Ukik, K. 2013).

Pertumbuhan penduduk di Indonesia cukup tinggi setiap tahun. Dilihat dari segi kuantitas jumlah penduduk Indonesia tahun 2015 cukup besar yaitu 252,5 juta jiwa, tetapi dari segi kualitas melalui Indeks Pembagunan Manusia kondisi Indonesia sangat memprihatinkan. Tingginya laju pertumbuhan yang tidak diiringi peningkatan kualitas penduduk ini terus dilakukan upaya penanganan yaitu dengan program keluarga berencana.

Paradigma baru program Keluarga Berencana Nasional telah diubah visinya dari mewujudkan Norma Keluarga Kecil Bahagia Sejahtera (NKKBS) menjadi visi untu mewujudkan "Keluarga Berkualitas Tahun 2015". Keluarga yang berkualitas adalah sejahtera, sehat, maju, mandiri, jumlah anak yang ideal, berwawasan kedepan, bertanggung jawab, harmonis dan bertakwa kepada Tuhan Yang Maha Esa.

Kontrasepsi hormonal adalah pilihan keluarga berencana yang paling banyak dipakai oleh akseptor.Kontrasepsi hormonal memiliki beberapa efek samping yaitu rasa mual, sakit kepala, flour albus, peningkatan berat badan, nyeri pada mammae, depresi dan ketidakteraturan siklus haid. Salah satu 
metode kontrasepsi modern dengan menggunakan suntik yang paling sering digunakan adalah (Depo Medroxy Progesteron Acetat) yang berasal dari hormon alamiah progesteron. Diberikan 3 bulan dengan dosis $150 \mathrm{mg}$ (Abdul, 2009).

Cakupan peserta keluarga berencana baru dan keluarga berencana aktif di Indonesia pada tahun 2017 dengan jumlah Pasangan Usia Subur sebanyak 63,22\%, sedangkat yang tidak pernah ber-KB sebesar 18,63\%. KB Aktif tertinggi terdapat di Bengkulu yaitu sebesar $71,98 \%$ dan yang terendah di papua sebesar 25,73\%. Terdapat lima provinsi dengan cakupan $\mathrm{KB}$ aktif kurang dari 50\% yaitu Papua, Papua Narat, Nusa Tenggara Timur, Maluku, dan Kepulauan Riau. Berdasarkan pola dala, pemilihan jenis alat Kontrasepsi sebagian peserta KB aktif memilih suntikan dan pil sebagai alat kontrasepsi bahkan sangan dominan (lebih dari $80 \%$ ) dibandingkan metode lainnya : suntikan (62,77\%) dan pil (17,24\%). Padahal suntikan dan pil termasuk dalam metode kontrasepsi jangka pendek sehingga tingkat efektifitas suntikan dan pil dalam pengendalian kehamilan lebih rendah dibandingkan jenis kontrasepsi lainnya (Depkes, 2017).

PUS di Bengkulu pada tahun 2017 yaitu sebesar 62.581 Pasangan. Peserta KB baru berjumlah $5.252(8,4 \%)$ terjadi peningkatan sebesar 0,1 dibandingkan dengan capaian tahun $20168,3 \%$ dan $\mathrm{KB}$ aktif berjumlah $46.914(75 \%)$ naik $0,9 \%$ jika dibandingkan dengan $74,1 \%$ cakupan jumlah peserta KB baru. Alat kontrasepsi yang digunakan Pasangan Usia Subur diurutkan dari yang tertinggi merupakan metode $\mathrm{KB}$ suntik $49,5 \%$, pil $18,7 \%$, Implan sebesar $13,6 \%$, IUD 10,7\%, Kondom 4,8\%, MOW 2,6\%, MOP 0,4\%.

Keluarga berencana atau disingkat $\mathrm{KB}$ merupakan program yang ada dihampir setiap negara berkembang, termasuk indonesia, program ini bertujuan untuk mengontrol jumlah penduduk dengan mengurangi jumlah anak yang dilahirkan oleh perempuan usia 1549 tahun, yang kemudian disebut dengan angka kelahiran total atau total fertility rate TFR. Dengan pengaturan jumlah anak tersebut diharapkan keluarga yang mengikuti program ini dapat meningkatkan kesejahteraan dan kualitas kehidupan mereka (Arikunto, 2010)

Berdasarkan penelitian oleh Riastini (2014) kontrasepsi hormonal suntik DepoMedroxyprogesterone Acetate (DMPA) merupakan salah satu metode kontrasepsi yang banyak digunakan. Kontrasepsi ini memiliki efektivitas yang baik, tetapi memiliki beberapa efek samping. Efek samping tersebut adalah gangguan haid berupa ketidakteraturan siklus haid, bercak perdarahan dan perdarahan di luar siklus haid, peningkatan berat badan dan flour albus pada penggunaan kontrasepsi DMPA. Penelitian ini bertujuan untuk mengetahui hubungan antara penggunaan kontrasepsi hormonal suntik DMPA dengan peningkatan berat badan. Penelitian dilakukan di Puskesmas Lapai Kota Padang, pada bulan Mei sampai Desember 2013. Jenis penelitian adalah analitik observasional dengan rancangan cross sectional. Sampel adalah akseptor yang telah menggunakan kontrasepsi DMPA minimal delapan kali, dengan jumlah 40 akseptor. Analisis data dilakukan secara bivariat dengan menggunakan uji T. Hasil penelitian menunjukkan 23 akseptor $(57.50 \%)$ mengalami peningkatan berat badan. Sebagian besar rata-rata peningkatan berat badan dalam satu tahun adalah $>0-1 \mathrm{~kg}$ (47.8\% akseptor). Rata rata berat badan sebelum dan setelah penggunaan kontrasepsi DMPA adalah $54.4 \mathrm{~kg}$ dan $58.1 \mathrm{~kg}$.

\section{METODE}

Jenis penelitian ini adalah kuantitatif, penelitian diarahkan untuk mendeskripsikan atau menguraikan suatu keadaan, dengan desain penelitian Cross Sectional dimana data yang menyangkut variabel independen dan variabel dependen dikumpulkan dalam waktu yang bersamaan (Notoadmodjo, 2010)

Instrumen yang digunakan dalam penelitian ini adalah kuesioner dengan 
menggunakan pertanyaan tertutup, kuesioner ini dikembangkan dalam peneliti sebelumnya. Penelitian menggunakan Skala Gutman dilakukan bila ingin mendapatkan jawaban yang tegas diantaranya ya dan tidak, benarsalah.

Kuesioner digunakan untuk memperoleh data tentang analisis hubungan ketidakteraturan siklus, peningkatan berat badan dan flour albus terhadap minat akseptor depoprogesteron untuk melanjutkan suntik depoprogesteron tahun 2018. Data yang diperoleh berupa skor hasil pengisian kuesioner dari responden. Kuesioner disebar setelah dilakukan uji validitas dan uji relibilitas. Uji coba dilakukan untuk mengetahui sejauh mana pemahaman responden terhadap pertanyaan-pertanyaan dari kuesioner yang dibuat.

Gambaran Daerah Penelitian atau Informasi Penelitian, sebelum melakukan penelitian dikumpulkan data dengan cara menggunakan data sekunder dan primer yang didapatkan dari Bps Bidan Resti Desa Sibak Provinsi Bengkulu.

Definisi operasional merupakan pengertian variabel (dalam definisi konsep) tersebut secara operasional, dan secara nyata dalam lingkup obyek penelitian atau obyek yang diteliti. Definisi operasional dalam penelitian ini adalah sebagai berikut:

1. Minat akseptor Depoprogesteron untuk melanjutkan suntik Depoprogesteron terhadap Dimana akseptor depoprogesteron memilih tidak melanjutkan atau melanjutkan saat menggunakan suntik depoprogesteron. Skala ukur yang digunakan adalah ordinal. Alat ukur yang digunakan adalah kuesioner, dengan penggolongan jawaban responden yaitu $0=$ tidak melanjutkan, 1 = melanjutkan.

2. Ketidakteraturan siklus haid terhadap Siklus haid normal 28 hari, siklus haid tidak normal $>30$ hari. Skala ukur yang digunakan adalah ordinal. Alat ukur yang digunakan adalah kuesioner, dengan penggolongan jawaban responden yaitu $0=$ tidak teratur, $1=$ teratur.

3. Peningkatan berat badan terhadap berat badan bertambah jika peningkatanya 1-5 $\mathrm{kg}$ pertahun. Skala ukur yang digunakan adalah ordinal. Alat ukur yang digunakan adalah ceklis, dengan penggolongan jawaban responden yaitu $0=$ tidak betambah $1=$ bertambah.

4. Flour albus terhadap keputihan normal tidak berbau, jernih,tidak gatal, keputihan tidak normal bau, gatal. Skala ukur yang digunakan adalah ordinal. Alat ukur yang digunakan adalah kuesioner, dengan penggolongan jawaban responden yaitu $0=$ tidak keputihan, $1=$ keputihan.

Populasi merupakan keseluruhan objek penelitian atau objek yang diteliti berupa orang, benda, gejala atau wilayah yang ingin diketahui penelitiyang menjadi populasi dalam penelitian ini adalah akseptor kb suntik depoprogesteron di wilayah bidan resti desa sibak jumlah populasi 297 orang. Sampel adalah subset yang di cuplik dari populasi, yang akan diamati dan di ukur oleh peneliti Sampel dalam penelitian ini berjumlah 170 orang. Cara pengambilan sampel dengan menggunakan accidental sampling yaitu pengambilan sampel yang dilakukan dengan mengambil kasus atauresponden yang kebetulan ada atau tersedia disuatu tempat sesuai dengan konteks penelitian. Sampel juga harus memenuhi kriteria inklusi, sehingga diperolehjumlah sampel yang diambil adalah 170 orang.

Instrumen penelitian yang digunakan adalah kuesioner dengan jenis kuesioner tertutup dimana responden tinggal memilih alternatif jawaban yang telah disediakan sesuai dengan petunjuk dengan tujuan supaya lebih mudah mengarahkan jawaban responden dan lebih mudah diolah. Peneliti membagikan kuesioner tersebut dengan memberikan penjelasan terlebih dahulu secara singkat tentang cara pengisian kuesioner yang diberikan. Teknik pengumpulan data dalam penelitian ini menggunakan data primer dan data sekunder.

Data primer dalam penelitian ini merupakan data yang diperoleh secara langsung dari responden dengan 
menggunakan Kuesioner yang telah disediakan data sekunder yaitu data yang diperoleh melalui pihak lain, tidak langsung diperoleh dari subjek penelitiannya data sekunder didapatkan dari data kunjungan ulang berat badan sebelumnya.

Validitas adalah suatu indeks yang menunjukkan alat ukur itu benar-benar mengukur apa yang diukur. Adapun hasil uji kuesioner setiap pertanyaan untuk masingmasing variabel dilakukan pada 27 responden dengan nilai $\mathrm{r}$ tabel pada tingkat kemaknaan $5 \%$ adalah 0,304. Setiap item pertanyaan yang berjumlah 42 soal dinyatakan valid.. Reliabilitas ialah indeks yang menunjukkan sejauh mana suatu alat pengukur dapat percaya atau dapat diandalkan Adapun uji reliabilitas pada setiap variabel dinyatakan reliable, yaitu variabel minat akseptor depoprogestero $\quad 0,794, \quad$ variabel ketidakteraturan siklus haid 0,763 , variabel flour albus 0,784, dengan tingkat reliabilitasnya adalah sangat realiabel $(>0,80$ $-1,00)$.

Analisa data adalah suatu metode yang digunakan untuk mengolah data hasil penelitian dalam memperoleh suatu kesimpulan analisa data diolah menggunakan sistem komputerisasi. Analisa univariat yaitu bertujuan untuk menjelaskan atau mendeskripsikan setiap variabel penelitian ${ }^{14}$. Analisa bivariat merupakan analisa untuk mengetahui interaksi dua variabel, baik berupa komparatif, asosiatif, maupun korelatif $^{14}$. Analisis bivariate digunakan untuk mengetahui hubungan antara variabel independen dan variabel dependen dengan menggunakan uji chi square.

Dalam bidang kesehatan untuk mengetahui derajat hubungan, dikenal ukuran resiko relative (RR) dan odss ratio (OR).Risiko relative membandingkan risiko pada kelompok terekspose dengan kelompok tidak terekspose. Sedangkan odss ratio membandingkan odd pada kelompok terekpose.

Ukuran RR pada umumnya digunakan pada desain kohort, sedangkan ukuran OR biasanya digunakan pada desain kasus control atau potong lintang (cross sectional) dan dalam penelitian ini peneliti menggunakan nilai OR.

\section{HASIL}

Tabel 1 Distribusi Frekuensi Minat Akseptor Depoprogesteron Untuk Melanjutkan Suntik Depoprogesteron, Ketidakteraturan Siklus Haid, Peningkatan Berat Badan dan Flour Albus, Di Bidan Resti Bengkulu Tahun 2018

\begin{tabular}{ccc}
\hline Variabel & N & \% \\
\hline $\begin{array}{c}\text { Minat Aksseptor } \\
\text { Depoprogesteron }\end{array}$ & \\
\hline Melanjutkan & 62 \\
\hline $\begin{array}{c}\text { Tidak } \\
\text { Melanjutkan }\end{array}$ & 37,1 \\
\hline \multicolumn{2}{c}{63} & \\
\hline Siklus Haid & 64,7 \\
\hline Teratur & 35,3 \\
\hline Tidak Teratur & 60 \\
\hline Peningkatan Berat Badan & \\
\hline Bertambah & 110 \\
\hline Tidak Bertambah & 46 \\
\hline Flour Albus & 27,1 \\
\hline Keputihan & 67 \\
\hline Tidak Keputihan & 103 \\
\hline
\end{tabular}

Sumber: Oleh data komputerisasi 2018

Berdasarkan tabel diatas dari 170 responden, akseptor yang memiliki minat akseptor depoprogesteron untuk melanjutkan suntik depoprogesteron adalah sebanyakn107 orang $(62,9)$ sedangkan yang tidak melanjutkan didapatkan sebanyak 63 orang $(37,1)$. Pada tabel 1 dari 170 responden, akseptor yang memiliki ketidakteraturan siklus haid yang teratur sebanyak 110 orang $(64,7 \%)$ sedangkan yang siklus haid yang tidak teratur 60 orang $(30,3 \%)$. Pada tabel I dari 170 orang Iresponden, akseptor yang memiliki peningkatan berat badan yang bertambah sebanyak 124 orang $(72,9)$ 
sedangkan yang peningkatan berat badan tidak bertambah sebanyak 46 orang $(27,1 \%)$. Pada tabel I dari 170 responden, akseptor yang memimiliki keputihan sebanyak 67 orang $(39,4 \%)$ sedangkan yang tidak keputihan sebanyak 103 orang $(60,6 \%)$.

Tabel 2 Ketidakteraturan Siklus Haid, Berat Badanb Dan Flour Albus Terhadap Akseptor Depoprogesteron Untuk Melanjutkan Suntik Bidan Resti Bengkulu 2018

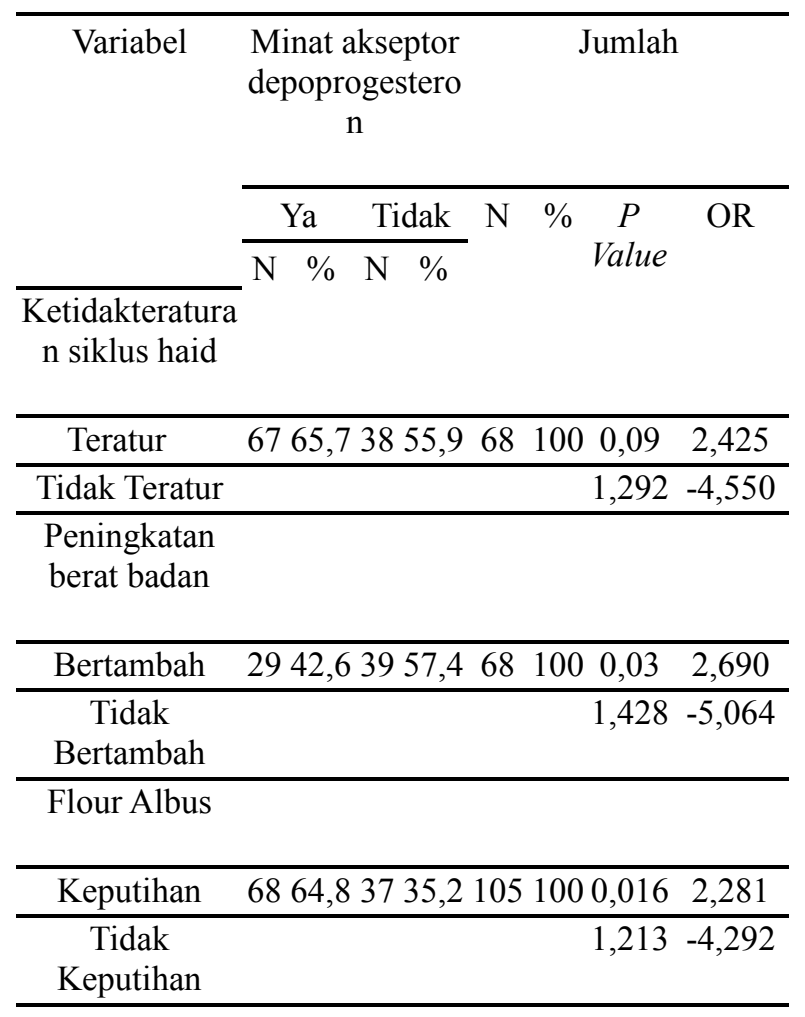

Berdasarkan tabel di bawah hasil analis hubungan antara peningkatan berat badan terhadap minat akseptor depoprogesteron untuk melanjutkan suntik depoprogesteron diperoleh bahwa ada sebanyak 39 responden $(57,4 \%)$ dari 68 responden tidak melanjutkanminat akseptor depoprogesteron untuk melanjutkan suntik depoprogesteron, tidak bertambah sedangkan ada sebanyak 34 responden $(33,3 \%)$ dari 102 responden melanjutkan minat akseptor depoprogesteron untuk melanjutkan suntik depoprogesteron.. Hasil uji statistik diperoleh nilai $\mathrm{p}=0,03$ maka dapat disimpulkan ada hubungan antara peningkatan berat badan.

Dari hasil analisis diperoleh nilai OR 2,690 artinya ibu yang peningkatan berat badanya tidak bertambah untuk melanjutkan depoprogesteron untuk melanjutkan suntik depoprogesteron diperoleh bahwa ada terhadap

sebanyak 37 responden (35\%) dari 105 minatakseptor depoprogesteron untuk melanjutkan suntik depoprogesteron, sebanyak responden (36\%) dari 65 responden tidak melanjutkan minat akseptor depoprogesteron untuk melanjutkan suntik depoprogesteron. Hasil uji statistik diperoleh nilai $\mathrm{p}=0,016$ maka dapat disimpulkan ada hubungan antara flour albus terhadap minat akseptor depoprogesteron untuk melanjutkan suntik depoprogesteron.

Dari hasil analisis diperoleh nilai OR 2,281 artinya ibu yang flour albus tidak keputihan untuk melanjutkan minat akseptor depoprogesteron untuk melanjutkan suntik depoprogesteron.

\section{PEMBAHASAN}

Minat merupakan salah satu aspek psikis yang dapat mendorong manusia mecapai tujuan.Seseorang yang memiliki minat terhadap suatu objek, cenderung memberikan perhatian atau merasa senang yang lebih besar kepada objek tersebut. Namun, apabila objek tersebut tidak menimbulkan rasa senang, maka orang itu tidak akan memiliki minat atas objek tersebut (Sri W, 2012).

Secara sederhana, minat (interest) berarti kecendrungan dan kegairahan yang tinggi atau keinginan yang besar terhadap sesuatu. Minat merupakan suatu dorongan yang kuat dalam diri seseorang terhadap sesuatu. Minat adalah rasa lebih suka dan rasa ketertarikan pada suatu hal atau aktivitas, tanpa ada yang menyuruh minat dapat timbul dengan sendirinya, yang tenggarai dengan adanya rasa suka terhadap sesuatu

Minat adalah keinginan yang di dorong oleh suatu keinginan setelah selesai melihat, mengamati dan membandingkan serta mempertimbangkan terhadap kebutuhan yang 
diinginkan.

Kontrasepsi suntik adalah alat kontrasepsi berupa cairan yang disuntikan ke dalam tubuh wanita secara periodik dan mengandung hormonal, kemudian masuk ke dalam pembuluh darah diserap sedikit oleh tubuh yang berguna untuk mencegah timbulnya kehamilan. Kontrasepsi hormonal jenis KB suntikan ini di Indonesia semakin banyak dipakai karena kerjanya yang efektif, pemakaiannya yang praktis, harganya relatif murah dan aman. Depoprogesterin atau DMPA adalah suatu jenis KB suntik yang mengandung $150 \mathrm{mg}$ Depo Medroxy Progesteron Acetat dan diberikan tiap 3 bulan sekali secara IM (Intra Muscular) (Wahid I, 2011)

Jenis kontrasepsi suntikan yang hanya mengandung progesterin yaitu Golongan progesteron, misalnya Depoprovera $150 \mathrm{mg}$ isi $1 \mathrm{cc}$ disuntikkan tiap tiga bulan. Depo progestin $150 \mathrm{mg}$ isi $3 \mathrm{cc}$ disuntikkan tiap 3 bulan, Golongan progestin dengan campuran esterogen propinate, misalnya sylofem disuntikkan tiap satu bulan. Terdapat dua jenis kontrasepsi hormon suntikan KB. Jenis yang beredar di Indonesia adalah yang mengandung hormon progesterone Depo Provero $150 \mathrm{mg}$, Depo Progestin $150 \mathrm{mg}$, Depo Geston $150 \mathrm{mg}$, Noristerat $200 \mathrm{mg}$, yang mengandung $25 \mathrm{mg}$ Medroxy progesteron acetat dan $5 \mathrm{mg}$ estradiol cypionate yaitu Cylofem (Handayani S, 2010).

Efektifitas kontrasepsi sangat efektif yaitu 0,1-0,4 mg kehamilan per 100 perempuan pertahun. Jenis kontrasepsi ini pada dasarnya mempunyai cara kerja seperti pil. Untuk suntikan yang diberikan 1 bulan sekali, memiliki keuntungan mengurangi resiko lupa minum pil dan dapat bekerja efektif selama 1 bulan. Efek samping biasanya terjadi pada wanita yang menderita diabetes atau hipertensi. Efektif bagi wanita yang tidak mempunyai masalah penyakit metabolik seperti diabetes, hipertensi, trombosis atau gangguan pembekuan darah serta riwayat stroke. Tidak cocok buat wanita perokok, karena rokok dapat menyebabkan penyumbatan pembuluh darah (Manuaba dkk, 2010) Indikasi kontrasepsi suntik depoprogesteron usia reproduksi, diberikan telah memiliki anak maupun yang belum memiliki anak, ingin mendapatkan kontrasepsi dengan efektivitas yang tinggi, pasca persalinan dan tidak menyusui, nyeri haid hebat sering lupa menggunakan pil kontrasepsi

Cara kerja suntik depoprogesteron yaitu menekan ovulasi kadar progestin tinggi sehingga menghambat lonjokan luteinizing hormon (LH) secara efektif sehingga tidak terjadi ovulasi. Kadar follicele stimulating hormon (FSH) dan ( $\mathrm{LH})$ menurun dan tidak terjadi lonjakan LH (LH surge). Menghambat perkembangan folikel dan mencegah ovulasi. Prpgesteron menurunkan frekuensi pelepasan (FSH) dan (LH). Membuat lendir serviks menjadi kental sehingga penetrasi sperma terganggu. Lendir serviks menjadi kental dan sedikit, mengalami penebalan mukus serviks yang menganggu penetrasi sperma. Perubahan-perubahan siklus yang normal pada lendir serviks. Secret dari serviks tetap dalam keadaan di bawah pengaruh progesteron sehingga menyulitkan penetrasi spermatozoa (Saifuddin, 2012).

Kontrasepsi suntik progestin memiliki efektifitas tinggi yaitu 0,3 kehamilan per 100 perempuan pertahun, asal penyuntikannya dilakukan secara teratur sesuai jadwal yang ditentukan. Tingginya minat pemakaian alat kontrasepsi ini olehkarena murah, aman, sederhana, efektif dan dapat dipakai pada pasca persalinan ( Kusmiran, 2014).

Keuntungan kontrasepsi suntik depoprogesteron yaitu sangat efektif, pencegahan kehamilan jangka panjang,tidak berpengaruh pada hubungan suami istri, tidak mengandung estrogen sehingga tidak berdampak serius terhadap penyakit jantung, dan gangguan pembekuan darah, tidak memiliki pengaruh terhadap ASI, klien tidak perlu menyimpan pil, sedikit efek samping, dapat digunakan oleh perempuan $>35$ tahun sampai perimenopause, membantu mencegah kanker endometrium dan kehamilan ektopik, menurunkan kejadian penyakit jinak 
payudara, mencegah beberapa penyebab penyakit radang panggul, menurunkan krisis anemia bulan sabit (sickle cell) (Apriyani, 2015).

Efek samping kontrasepsi suntik depoptogesteren yaitu gangguan haid ini yang paling sering terjadi amenorhe, spotting dan metrorhagia. Pola haid yang normal dapat terjadi amenorhe, perdarahan ireguler, perdarhan bercak, perubahan dalam frekuensi yang lama. Efek pada pola haid tergantung pada lama pemakaian. Perdarahan ini termenstrular dan perdarahan bercak berkurang dengan jalannya waktu, sedangkan kejadian amenorea bertambah besar. Insiden yang tinggi dari amenore diduga berhubungan dengan atropi endometrium, sedangkan sebab-sebab dari perdarahan ireguler masih belum jelas, dan nampaknya tidak ada hubungan dengan perubahan dalam kadar hormon. DMPA lebih sering menyebabkan perdarhan. Amenore adalah tidak datangnya haid pada setiap bulan selama akseptor mengikuti KB suntik.

Ketidakseimbangan hormon pada repsoduksi wanita yang mana diketahui hormon tersebut harus dalam komposisi yang tepat untuk mengetahui kapan pembentukan sel telur pada indung telur. Pada wanita siklus haid rata-rata terjadi sekitar 28 hari, walaupun hal ini berlaku umum, tetapi tidak semua wanita memiliki siklus haid yang sama, kadang-kadang siklus terjadi setiap 21 hari hingga 30 hari. Biasanya haid rata-rata 5 hari, kadang-kadang haid juga dapat terjadi sekitar 2 hari sampai 7 hari. Umumnya darah yang hilang akbibat menstruasi adalah $10 \mathrm{ml}$, hingga $80 \mathrm{ml}$ per hari tetapi biasanya dengan rata-rata $35 \mathrm{ml}$ per harinya.

Peningkatan berat badan adalah berubahnya ukuran berat, baik bertambah atau berkurang akibat dari konsumsi makanan yang diubah menjadi lemak dan disimpan di bawah kulit. Pada pemakain kontrasepsi jenis suntik terdapat salah satuefek samping yang mengabikatkan peningkatan berat badan. Peningkatan berat badan yang berlebihan merupakan salah satu efek samping dari penggunaan kontrasepsi 3 bulanan. Namu tidak semua akseptor mengalami mengalamipeningkatan berat badan, karena efek obat tersebut tidak selalu sama pada masing-masing individu (Kadus D, 2009).

Pengukuran berat badan digunakan untuk menilai hasil peningkatan atau penurunan semua jaringan yang ada pada tubuh, misalnya tulang, otot, organ tubuh, dan cairan tubuh sehingga dapat diketahui status gizi dan tumbuh kembang.Berat badan juga dapat digunakan sebagai dasar penghitung dosis dan makanan yang diperllukan dalam tindakan pengobatan (Suratun dkk, 2008)

Kontrasepsi suntik umumnya menyebabkan pertambahan berat badan yang bervariasi antara 1-5 $\mathrm{kg}$ dalam tahun pertama.Bertambahnya berat badan terjadi karena bertambahnya lemak tubuh. Merangsang pusat pengendali nafsu makan di hipotalamus yang menyebabkan akseptor makan lebih dari pada biasanya (Pusmaika R. 2010).

Flour albus adalah suatu cairan selain darah yang keluar dari liang vagina yang berwarna putih seperti sagu, kekuningkuningan atau kental baik yang berbau atau tidak berbau. Flour albus dapat bersifat fisiologis maupun patologis dan merupakan manifestasi gejala dari hampir semua penyakit kandungan (Wiknjasastro, 2007).

Penyebab keputihan secara umum menurut Kuncoro yaitu memakai pakaian dalam yang ketat dari bahan sintetis, memakai pentyliner dan jarang menggantinya, melakukan personal hygine yang salah, Sering bertukar celana dalam atau handuk dengan orang lain, kebersihan vagina yang kurang terjaga, kelelahan yang amat sangat, mengalami stress, memakai sembarang sabun untuk membasuh vagina Hormon yang tidak seimbang, sering berganti-ganti pasangan dalam melakukan hubungan sex (Kuncoro, 2012).

Faktor-faktor yang berhubungan dengan kejadian keputihan seperti pekerjaan. Pekerjaan ibu adalah kegiatan sehari-hari yang dilakukan oleh seorang ibu dengan maksud untuk memperoleh penghasilan. Keputihan tidak bisa dipungkiri salah satunya 
oleh kondisi fisik wanita yang terkuras energi maupun psikisnya sebab mengerjakan pekerjaan berat atau aktivitas ekstra lainnya. Penyebab keputihan dari keletihan ditandai muncul hanya pada waktu kondisi tubuh sangat capek dan biasa lagi ketika tubuh sudah normal kembali. Banyak wanita mengeluhkan keputihan sangat tidak nyaman, gatal, berbau bahkan terkadang perih. Salah satu penyebabnya yaitu masalah kebersihan pada organ intim. Salah satu penyebabnya yaitu masalah kebersihan pada organ intim. Bila ingin terhindar dari keputihan, wanita harus selalu menjaga kebersihan daerah genetalia. Mencuci vagina dengan air kotor, pemeriksaan dalam yang tidak benar, penggunaan pembilas vagina yang berlebihan, pemeriksaan yang tidak haigines, dan adanya benda asing dalam vagina dapat menyebabkan keputihan abnormal. Vulva haigine merupakan salah satu tindakan untuk memelihara kebersihan kewanitaan bagian luar vulva yang dilakukan untuk mempertahankan kesehatan dan mencegah infeksi (Bahari, 2012)

Estrogensebagai kontrasepsi bekerja dengan jalan menghambat ovulasi melalui fungsi hipotalamus-hifofosisi-ovarium, menghambat perjalanan ovum atau implantasi. Sedangkan progesterone bekerja dengan cara membuat lender serviks lebih kental hingga penetrasi dan transportasi sperma, perjalanan ovum dalam tuba, implantasi dan menghambat ovulasi melalui fungsi hipotalamus-hipofosis-ovarium. Efek samping pemberian kontrasepsi hormonal sesuai dengan kadar hormon yang dikandungannya kelebihan hormon estrogen dapat menimbulkan keputihan.

Mikroorganisme yang dapat menyebabkan terjadinya keputihan Jamur Candida albicansul merupakan jamur yang tidak menimbulkan gejala, tetapi dalam keadaan tertentu dapat menyebabkan gejala infeksi dari mulai yang ringan sampai berat. Keputihan yang disertai gejala atau tanpa gejala tetapi jika dilakukan pembikan sekret vagina akan terlihat jamur candida. Parasit dapat juga menyebabkan keputihan adalah
Trichomonas vaginalis yang berbentuk lonjong, bersilia, dan dapat bergerak berputar putar secara cepat. Penyakit ini dapat menular dengan berbagai cara, namun paling efektif dengan jelan coitus. Gejala yang ditimbulkan adalah flour albus yang encer sampai kental, berwarna kekuningan, agak bau, serta terasa panas dan gatal (Wijanti, 2009)

\section{Hubungan ketidakteraturan siklus haid terhadap akseptor depoprogesteron untuk melanjutkan suntik depoprogesteron}

Hasil peneliti menunjukkan bahwa ketidakteraturan siklus haid yang terbanyak adalah pada golongan tidak teratur yaitu sebesar 34,3\%. Diperoleh nilai Pvalue= 0,009 lebih kecil dari a $(0,05)$ yang berati Ho ditolak ada hubungan anatara minat akseptor depoprogesteron untuk melanjutkan suntik depoprogesteron dengan ketidakteraturan siklus haid. Selain itu nilai Odss Ratio (OR) sebesar 2,425 dengan tingkat kepercayaan 170\% CI (1,294 -4,550). Disimpulkan bahwa responden yang memiliki ketidakteraturan siklus haid untuk melanjutkan suntik depoprogesteron dibandingkan dengan responden tidak melanjutkan yang ketidakteraturan siklus haid teratur.

Menurut (Septia Nur Pratiwi, 2012) Dari hasil analisa data yang dilakukan peneliti Septia Nur Pratiwi dengan menggunakanChi-Square diperoleh $\rho=0,000$ dimana nilai $\rho \leq 0,05$ yang berarti bahwa $\mathrm{H} 0$ ditolak, sehingga terdapat hubungan antara pemakaian metode kontrasepsi depoprogesteron dengan ketidakteraturan siklus haid pada ibu usia subur di Puskesmas Pakis Surabaya. Dari hasil penelitian didapatkan bahwa dari 33 responden yang memakai kontrasepi hormonal sebanyak 23 orang $(69,7 \%)$ dan yang mengalami siklus haid sebanyak 18 orang $(54,5 \%)$ sedangkan yang tidak mengalami siklus haid p 5 orang $(15,2 \%)$. Sedangkan pada kontrasepsi non hormonal didapatkan 10 orang (30,3\%), yang terdiri dari 1 orang $(3 \%)$ yang mengalami ketidakteraturan siklus haid dan 9 orang $(27,3 \%)$ tidak mengalami ketidakteraturan 
siklus haid.

Hasil penelitian ini sejalan dengan hasil peneliti Nurwati tahun 2014 di Puskesmas hasil analisis dengan Chi Square untuk mengetahui suntik depoprogesteron di dapat $p$-Value $=0,08$, sehingga dapat disimpulan ada hubungan yang bermakna ketidakteraturan siklus haid dengan suntiik depoprogesteron. ${ }^{34}$

Berdasarkan uji statistic yang dilakukan, penulis berasumsi bahwa ketidakteraturan siklus haid mempengaruhui perubahan hormonal, usia, strers dan kelelahan, sehingga hal ini sangat berpengaruh terhadap suntik depoprogesteron.

\section{Hubungan peningkatan berat badan terhadap akseptor depoprogesteron untuk melanjutkan suntik depoprogesteron}

Hasil penelitian menunjukkan bahwa peningkatan berat badan responden yang terbanyak berasal dari meningkat adalah peningkatan berat badan yaitu sebesar \%. Diperoleh nilai Pvalue $=0,03$ lebih kecil dari a $(0,05)$ yang berarti Ho ditolak ada hubungan antara minat akseptor depoprogesteron untukmelanjutkan suntik depoprogesteron dengan peningkatan berat badan. Selain itu didapatkan nilai Odds Ratio sebesar 2,690 dengan kepercayaan 170\% CI (1,213-4,292).

Disimpulkan bahwa responden yang peningkatan berat badan dari tidak meningkat berpeluang kali lebih melanjutkan dalam minat akseptor depoprogesteron untuk melanjutkan suntik depoprogesteron di wilayah Puskesmas Ipuh Desa Sibak dengan responden yang peningkatan berat badan berasal dari meningkat.

Pendapat lainnya menyatakan penggunaan jangka panjang kontrasepsi suntik dapat memicu terjadinya peningkatan berat badan, gangguan emosi, dan jerawat karena penggunaan suntikan hormonal yang lama dapat mengganggu keseimbangan hormon estrogen dan progesteron dalam tubuh sehingga mengakibatkan terjadi perubahan sel yang normal menjadi tidak normal. Risiko kenaikan berat badan kemungkinan disebabkan karena hormon progesteron yang mempermudah perubahan karbohidrat dan gula menjadi lemak, sehingga lemak di bawah kulit bertambah, selain itu hormon progesteron juga menyebabkan nafsu makan bertambah dan menurunkan aktivitas fisik, akibatnya pemakaian kontrasepsi suntik.

\section{Hubungan flour albus terhadap minat akseptor depoprogesteron untuk melanjutkan suntik depoprogesteron}

Hasil penelitian menunjukkan bahwa flour albus responden yang terbanyak berasal dari meningkat adalah tidak keputihan yaitu sebesar 35,2\%. Diperoleh nilai Pvalue=0,014 lebih besar dari a $(0,05)$ yang berarti Ho ditolak ada hubungan antara minat akseptor depoprogesteron untuk melanjutkan suntik depoprogesteron dengan flour albus. Selain itu didapatkan nilai Odds Ratio sebesar 2,281 dengan kepercayaan 170\% CI (1,213-4,292). Disimpulkan bahwa responden yang flour albus dari tidak keputihan berpeluang kali lebih melanjutkan dalam minat akseptor depoprogesteron untuk melanjutkan suntik depoprogesteron di wilayah Puskesmas Ipuh Desa Sibak dengan responden yang keputihan.

Menurut penelitian Fakhidah tahun 2014 bahwa kejadian keputihan dapat dipengaruhui oleh lama pemakaian kontrasepsi hormonal karena ketidakseimbangan hormon dalam tubuh wanita. Ketidakstabilan ekosistem pada vagina akan menyebabkan keputihan, kestabilan ekosistem vagina akan dapat dipengaruhui sekresi (keluarnya lendir) statur hormonal (masa pubertas, kehamilan, menopause), benda asing Intra Uterine Devices tampon dan obat yang dimasukan di dalam vagina. Obat-obatan (kontrasepsi). Terjadinya keputihan dalam menggunakan suntik depoprogesteron karena hormon progesteron mengubah flora dan $\mathrm{pH}$ vagina, sehingga jamur mudah tumbuh dan menimbulkan keputihan.

Hasil peneliti sejalan dengan hasil peneliti Hesti pajar sari tahun 2015 peneliti menggunakan Chi Square dan jika nilai $<5,0$ di dapatkan variabel yang memili hubungan 
dengan kejadiaan flour albus yaitu minat suntik depoprogesteron dengan nilai $\mathrm{p}$ sebesar $0.012<0,05$ dan sebesar 0,289, maka kekuatan hubungan rendah (0,20-0,399).

Berdasarkan uji statistik yang dilakukan, penulis berasumsi bahwa Flour Albus merupakan pengaruh suntik depoprogesteron dan merupakan masalah bagi akseptor, karena flour albus dan mempengaruhui akseptor suntik depoprogesteron.

\section{KESIMPULAN}

Dari hasil penelitian yang telah dilakukan oleh peneliti yang berjudul hubungan ketidakteraturan siklus haid, peningkatan berat badan, flour albus terhadap minat akseptor depoprogesteron untuk melanjutkan suntik depoprogesteron di wilayah bidan Resti Desa Sibak Provinsi Bengkulu Tahun 2018 dapat disimpulkan sebagai berikut:

Dari hasil penelitian didapatkan $64,7 \%$ responden yang siklus haidnya teratur, $74,7 \%$ responden berat badanya bertambah, $72,9 \%$ responden yang mengalami flour albus, $62,9 \%$ responden yang melanjutkan suntik depoprogesteron di Wilayah Bidan Resti Desa Sibak Provinsi Bengkulu Tahun 2018.

Ada hubungan antara ketidakteraturan siklus haid terhadap minat akseptor depoprogesteron untuk melanjutkan suntik depoprogesteron dg OR 2,425(1,292-4,550) di Wilayah Bidan Resti Desa Sibak Provinsi Bengkulu Tahun 2018.

Ada hubungan antara peningkatan berat badan terhadap minat akseptor depoprogesteron untuk melanjutkan suntik depoprogesteron dg OR 2,690 (1,428-5,064) di Wilayah Bidan Resti Desa Sibak Provinsi Bengkulu Tahun 2018.

Ada hubungan antara flour albus terhadap minat akseptor depoprogesteron untuk melanjutkan suntik depoprogesteron dg OR 2,281 (1,213-4,292) di Wilayah Bidan Resti Desa Sibak Provinsi Bengkulu Tahun 2018.

\section{SARAN}

Untuk memahami akseptor depoprogesteron dalam ber $\mathrm{kb}$, minat akseptor depoprogesteron akseptor depoprogesteron selanjutnya lebih baik dalam mendapatkan kenyamnan dalam ber kb.

Hasil penelitian ini diharapkan dapat dijadikan sebagai masukan informasi yang bertujuan untuk memberikan minat akseptor depoprogesteron untuk melanjutkan suntik depoprogesteron untuk melanjutkan suntik depoprogesteron.

Dapat melakukan peneliti lebih lanjut dengan variabel yang diteliti dan analisa dengan metode penelitiaan kualitatif maupun dianalisa sampai pada analisa multivariat.

\section{DAFTAR PUSTAKA}

Abdul S. 2009. Panduan Praktis Pelayanan Kontrasepsi. Jakarta: Yayasan Bina Pustaka-Sarwono Prawirohardjo.

Apriyani Y. 2009. Rekomendasi Praktik Pilihan Untuk Penggunaan Kontrasepsi. Jakarta EGC.

Arikunto S. 2010. Prosedur Penelitian Pendekatan Praktik. Yogyakarta : Rineka Cipta.

Bahari. 2012. Cara Mudah Atasi Keputihan. Jogjakarta : Buku Biru.

Depkes RI. 2017. Presentase KB Aktif Menurut Metode Kontrasepsi Indonesia.

Ernawati. 2010. Pemasaran Industri Jasa Kesehatan. Yogyakarta: Andi Offset.

Handayani S.2010. Buku Ajar Pelayanan Keluarga Berencana.Yogyakarta : Pustaka Rihama.

Kasdu D. 2009. Problem dan Solusi Kesehatan Reproduksi Wanita. Jakarta : Selemba Medika.

Kuncoro. 2012. Gejala penyebab dan pencegahan keputihan.

Kusmiran. 2011. Kesehatan Reproduksi remaja dan wanita. Jakarta : Selemba Medika.

Manuaba, dkk. 2010. Ilmu Kebidanan, Penyakit Kandungan dan KB. Jakarta : EGC. 
Marmi. 2015. Buku Ajar Pelayanan KB.Yogyakarta : Pustaka Belajar.

Maulana. 2009. Promosi Kesehatan. Jakarta : EGC.

Notoadmodjo S. 2010. Metodologi Penelitian Kesehatan. Jakarta : PT Rineka Cipta.

Prawirohardjo S. 2008. Ilmu Kandungan Jakarta : Yayasan Bina Pustaka.

Profil Kesehatan Provinsi Bengkulu . 2017

Pusmaika R. 2010. Kesehatan Reproduksi Wanita. Jakarta : Trans Info Media.

Saifuddin A. 2012. Buku Panduan Praktisi Pelayanan Keluarga Berencana. Jakarta :Yayasan Bina Pustaka Sarwono Prawirohardjo.

Setiyanigrum. 2014. Pelayanan Keluarga Berencana \& Kesehatan Reproduksi. Jakarta : TIM.

Sri W. 2012. Deskritif Teoritik Minat Belajar.

Suratun, dkk. 2008. Pelayanan Keluarga Berencana dan Pelayanan Kontrasepsi. Jakarta: Trans Info Media.

Ukik K. dkk. 2013. Kinerja Penyuluhan Keluarga Berencana di Indonesia: Pedoman Pengujian Efektivitas Kinerja pada Era Desentralisasi. Jurnal Kesehatan Masyarakat Nasional..

Wahid I. 2011. Promosi Kesehatan Untuk Kebidanan. Jakarta : Selemba Medika.

WHO. 2015. Word Health Organization.

Wijanti. 2009. Kesehatan Reproduksi \& Kontrasepsi. Jakarta : Trans Info Media.

Wiknjosastro, H. 2007. Ilmu Kandungan. Jakarta : Yayasan Bina Pustaka Sarwono Prawirohardjo. 